\title{
HERITAGE AND CONSERVATION
}

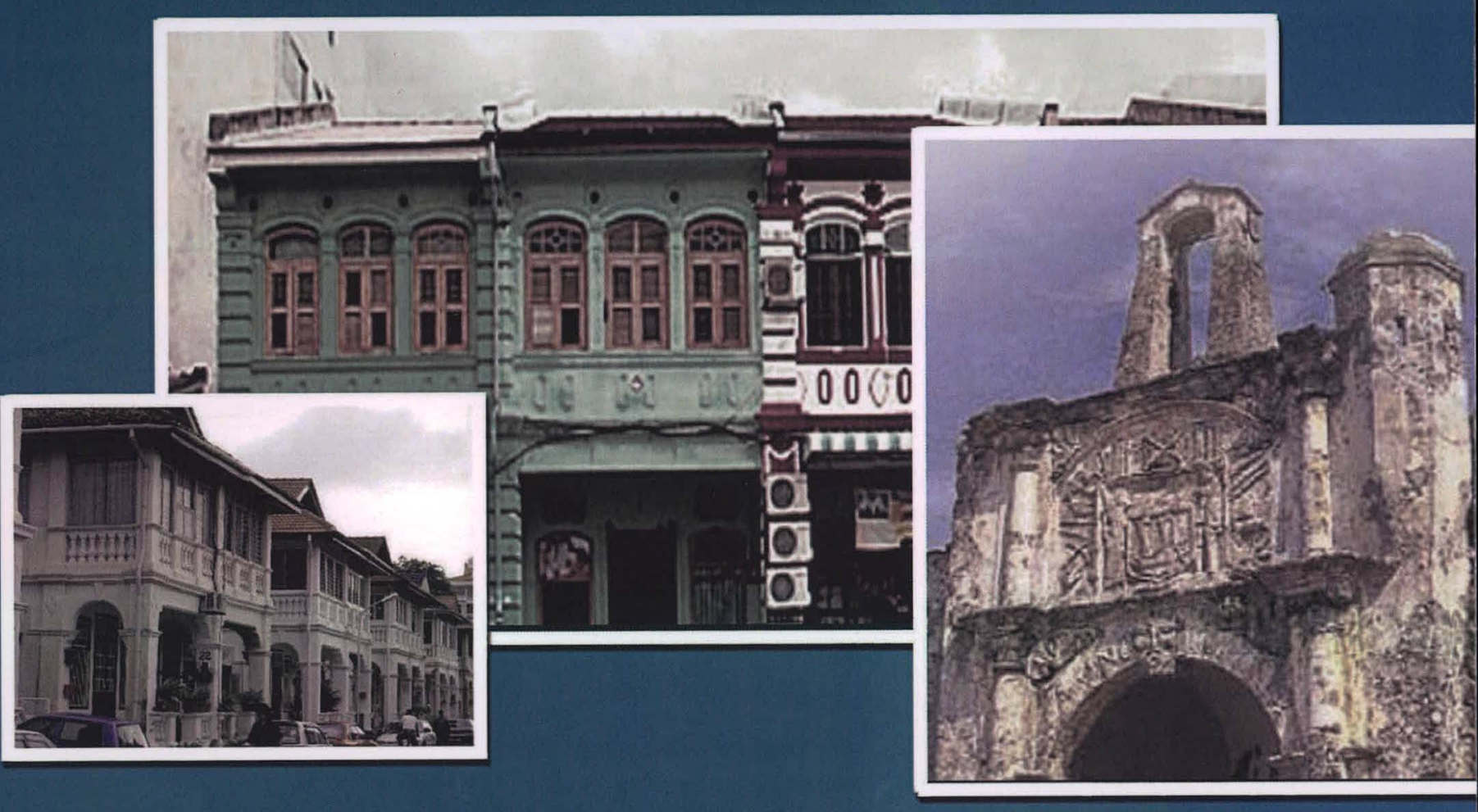

MANSOR IBRAHIM ASIAH ABDUL RAHIM ISMAWI HJ ZEN MANDANA BARKESHLI

$$
\text { 兟? }
$$

\section{IIUM PRESS}




\title{
HERITAGE
}

\section{AND}

\section{CONSERVATION}

Edited By

\author{
Mansor Ibrahim \\ Asiah Abdul Rahim \\ Ismawi Hj Zen \\ Mandana Barkeshli
}

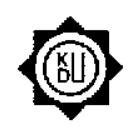

KAED Universal Design Unit, KAED

International Islamic University Malaysia (IIUM) Kuala Lumpur MALAYSIA

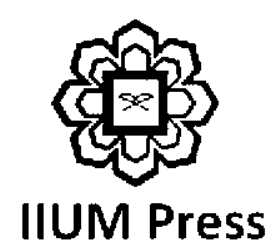


Published by:

IIUM Press

International Islamic University Malaysia

First Edition, 2011

CIIUM Press, IIUM

All rights reserved. No part of this publication may be reproduced, stored in a retrieval system, or transmitted, in any form or by any means, electronic, mechanical, photocopying, recording, or otherwise, without any prior written permission of the publisher.

Perpustakaan Negara Malaysia Cataloguing-in-Publication Data

ISBN: $978-967-418-129-1$

Member of Majlis Penerbitan Ilmiah Malaysia - MAPIM

(Malaysian Scholarly Publishing Council)

Printed by:

IIUMI PRINTING SDN.BHD.

No. 1, Jalan Industri Batu Caves 1/3

Taman Perindustrian Batu Caves

Batu Caves Centre Point 68100 Batu Caves

Selangor Darul Ehsan

Tel: +603-6188 1542 / 44 / 45 Fax: +603-61881543

EMAIL: iiumprinting $(a)$ yahoo.com 


\section{Contents}

\section{Acknowledgements}

Chapter 1 Environmental Crime Prevention Measures for Kindergarten LandscapeArea

Nur Amalina Ali Mohamad and Ismawi Hj Zen

Chapter 2 Documentation and Preservation of Melaka Shophouse Noorfadhilah Mohd Baroldin, Kamarul Bahrin Buyong and Shamzani Affendy Mohd Din

Chapter 3 Identification of Physical Problems on 19th Century Malay Manuscripts from Malay Peninsula: A Study from Visual Observation

Sharifah Tahirah Syed Kamarulzaman, Mandana Barkeshli and Shamzani Affendy Mohd Din

Chapter 4 Historical Malay World Qur'ans: An Investigation on Material Technology of the Colorants

Rajabi Abdul Razak and Mandana Barkeshli

Chapter 5 Evaluating Traditional Measures for the Care of Keris From Scientific Point of View

Muktaruddin Musa, Mohd Hanafi Ani, Mandana Barkeshli and Raihan Othman

Chapter 6 From Tamezuki to Samarghandi Paper: A New Approach to Restoration Technique of Islamic Paper Manuscripts Mandana Barkeshli

Chapter 7 Intangible Cultural Heritage (ICH): Understanding and Manifestations 
Aisyah Abu Bakar, Mariana Mohamed osman and Syahriah Bachok

Chapter 8 Islamic Values and Veil Architecture: Case Study Traditional Iranian Courtyard Houses

Fatin Zahida Abu Hassan and Asiah Abdul Rahim 